\title{
Analisis Pengaruh Perubahan Geometri Suspensi terhadap Dinamika Getaran Sepeda Motor
}

\author{
Mukhamad Ilham Alfian dan Unggul Wasiwitono \\ Departemen Teknik Mesin, Fakultas Teknologi Industri, \\ Institut Teknologi Sepuluh Nopember (ITS) \\ e-mail: unggul@me.its.ac.id
}

\begin{abstract}
Abstrak-Sistem suspensi mempunyai peranan penting pada kendaraan sebagai penunjang kenyamanan dan keselamatan berkendara. Berbagai usaha telah dilakukan untuk meningkatkan performa sistem suspensi, salah satunya dengan menggunakan sistem suspensi aktif. Kebutuhan terhadap energi yang sangat besar pada sistem suspensi aktif menginspirasi banyak peneliti untuk meningkatkan performa sistem suspensi dengan kebutuhan energi yang tidak terlalu besar. Selain pemilihan pegas dan peredam yang sesuai, geometri sistem suspensi juga mempunyai pengaruh yang signifikan terhadap kinematika dan dinamika sistem suspensi. Sehingga salah satu usaha untuk meningkatkan performa sistem suspensi adalah dengan memanipulasi geometri sistem suspensi atau yang dikenal sebagai variable geometry suspension. Pada penelitian ini akan dianalisis pengaruh perubahan geometri terhadap dinamika getaran sistem suspensi roda belakang sepeda motor. Perubahan geometri yang dianalisis adalah perubahan posisi bottom mounting suspensi dan panjang link untuk konstanta kekakuan pegas yang juga divariasikan. Dari hasil simulasi diperoleh bahwasanya apabila semakin dekat jarak bottom mounting suspensi dengan titik mounting pada connecting rod, maka semakin kecil respon percepatan yang diperoleh. Jika link semakin panjang, maka semakin kecil pula nilai respon percepatan yang diperoleh. Dan apabila semakin kecil kekakuan pegas yang digunakan, semakin kecil respon percepatan yang diperoleh. Selain itu, berdasarkan hasil simulasi, dibandingkan dengan suspensi Pro-Link, sistem suspensi yang dipelajari pada penelitian ini memberikan respon percepatan yang lebih baik.
\end{abstract}

Kata Kunci-bottom mounting suspensi, geometri suspensi, Honda CBR 150R, panjanglink, respon percepatan.

\section{PENDAHULUAN}

$\mathrm{S}_{\mathrm{n}}^{\mathrm{s}}$ USPENSI kendaraan bermotor dapat diklasifikasikan menjadi 3 jenis, yaitu suspensi pasif, semi-aktif, dan aktif [1]. Hingga saat ini jumlah penggunaan suspensi pasif masih mendominasi. Karena dibandingkan dengan suspensi semiaktif dan aktif harganya lebih murah, konstruksinya lebih sederhana, dan lebih mudah untuk diaplikasikan. Namun dalam hal keamanan, kenyamanan, dan performa dinamis masih lebih rendah dibandingkan suspensi semi-aktif dan aktif. Suspensi semi-aktif dan aktif lebih handal dalam meniminalkan efek ketidakrataan jalan terhadap pengendara. Tetapi konstruksinya yang rumit dan konsumsi energinya yang besar menjadi kekurangan dua jenis suspensi ini [2]. Oleh karena itu dikembangkan variable geometry suspension untuk mengatasi hal tersebut.

Melalui aktuator aktifnya, variable geometry suspension memanipulasi bentuk geometrinya untuk mendapatkan koefisien pegas tertentu sedemikian hingga dapat memenuhi tingkat kenyamanan yang diinginkan. Berbeda dengan suspensi aktif konvensional lainnya, variable geometry suspension bersifat fail-safe system, artinya jika aktuatornya tidak dapat menyalurkan gaya aktuasi, maka variable geometry suspension dapat berfungsi selayaknya suspensi pasif. Konstruksinya yang relatif lebih sederhana dan lebih ringan, serta gaya aktuasinya yang lebih rendah [2], menjadikan penerapan variable geometry suspension tidak hanya terbatas pada kendaraan bermotor roda empat [3][4][5][6], dan [7], melainkan juga dapat diterapkan pada roda dua [8]. Penerapannya pada sepeda motor dengan menggunakan kontrol aktif juga telah dilakukan oleh Simos Evangelou [9]. Pada penelitian tersebut [9] terdapat dua tujuan yaitu penggunaan fungsi levelling pada pembebanan yang berbeda dan saat bermanuver, serta stabilisasi pada saat berbelok dengan kecepatan tinggi.

Secara umum, penelitian ini bertujuan untuk mempelajari pengaruh perubahan geometri pada suspensi terhadap dinamika getaran pada Honda CBR 150R. Secara khusus, penelitian ini mempelajari pengaruh pergeseran posisi bottom mounting suspensi dan panjang link terhadap respon getaran yang ditimbulkan, serta pengaruh nilai kekakuan pegas untuk pada sistem suspensi Honda CBR 150R.

Garis besar artikel ilmiah ini yaitu sebagai berikut: Pada Bagian II dijelaskan pemodelan sistem suspensi konvensional Pro-Link dan suspensi dengan adanya perubahan geometri. Bagian III mencakup hasil simulasi dan diskusi. Sedangkan Bagian IV berisi kesimpulan dari penelitian ini serta saran untuk penelitian selanjutnya. 


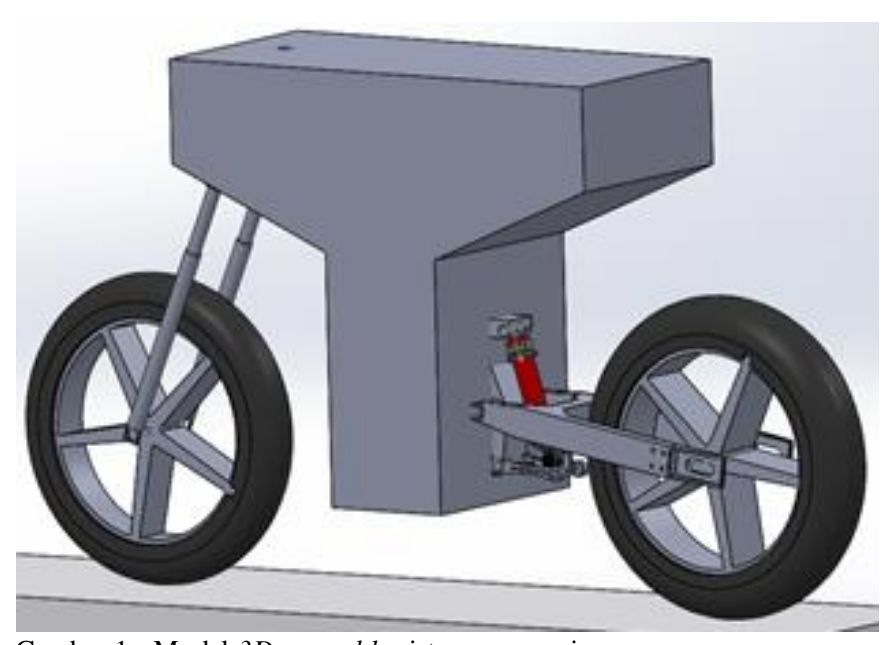

Gambar 1. Model 3D assembly sistem suspensi.

\section{PEMODELAN SISTEM SUSPENSI}

\section{A. Suspensi Pro-Link}

Model sistem suspensi sepeda motor yang digunakan sebagai pembanding dalam penelitian ini adalah Honda CBR 150R. Sistem suspensi belakang pada Honda CBR 150R dikenal dengan sebutan suspensi Pro-Link. Model simulasi dinamis dibuat dengan menggunakan numerical software, model $3 D$ assembly model half-car ini ditunjukkan oleh Gambar 1.

Tabel 1.

Parameter kendaraan

\begin{tabular}{lr}
\hline \hline Parameter & Nilai \\
\hline Massa total kendaraan & $135 \mathrm{~kg}$ \\
Massa pengendara & $70 \mathrm{~kg}$ \\
Massa unsprung depan & $15 \mathrm{~kg}$ \\
Massa unsprung belakang & $20 \mathrm{~kg}$ \\
Konstanta kekakuan suspensi depan & $18 \mathrm{kN} / \mathrm{m}$ \\
Redaman suspensi depan & $2 \mathrm{kNs} / \mathrm{m}$ \\
Redaman suspensi belakang & $3 \mathrm{kNs} / \mathrm{m}$ \\
Jarak sumbu roda & $1311 \mathrm{~mm}$ \\
Ukuran ban depan & $100 / 80-17^{*}$ \\
Ukuran ban belakang & $130 / 70-17^{*}$ \\
Jarak terendah ke tanah & $166 \mathrm{~mm}$ \\
\hline \hline
\end{tabular}

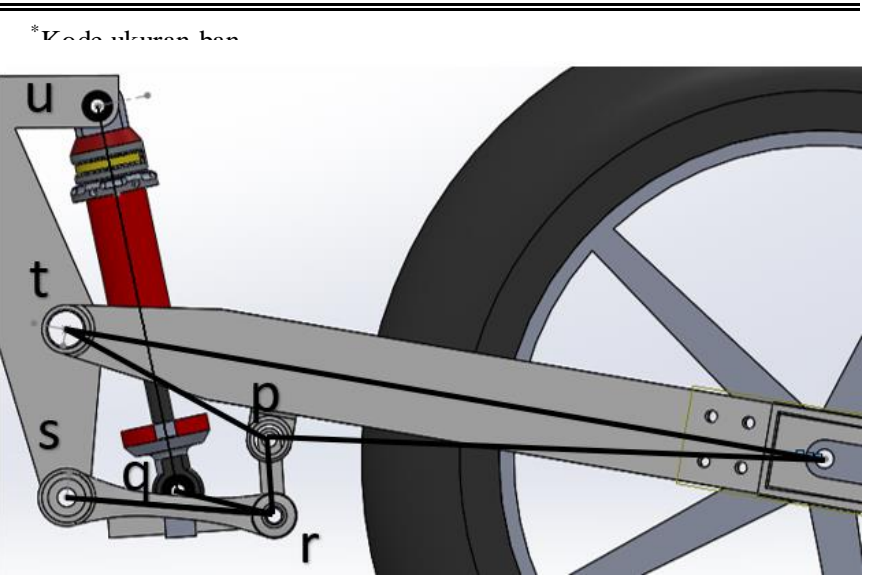

Gambar 2. Sistem suspensi belakang tampak samping kiri.

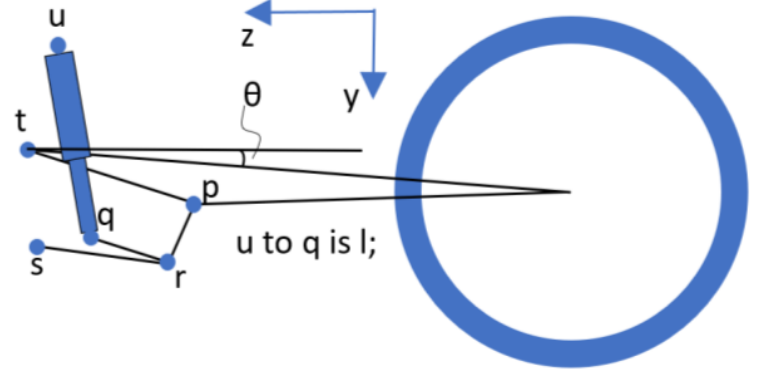

Gambar 3. Diagram sistem suspensi belakang.

Pada simulasi tugas akhir ini terdapat beberapa parameter kendaraan yang digunakan. Parameter kendaraan yang dimodelkan dapat dilihat pada Tabel 1. Pada numerical software, parameter tersebut digunakan sebagai acuan dalam membuat gambar 3D assembly pada Gambar 1. Parameter pada model ini juga digunakan untuk memodelkan dan mensimulasikan sistem dengan perubahan geometri suspensi belakang seperti yang ditunjukkan Gambar 2. Sistem suspensi

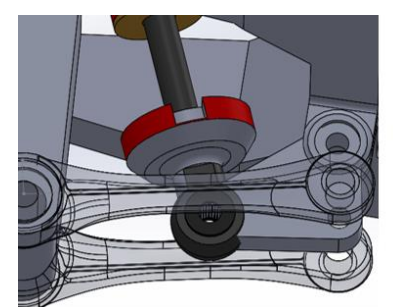

(a)

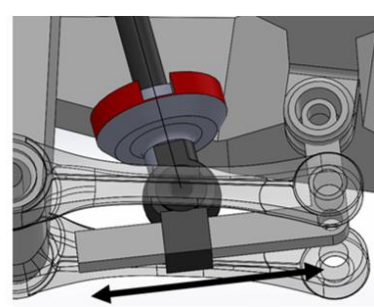

(b)
Gambar 4. Geometri link pada sistem suspensi (a) Pro-Link; (b) Sistem suspensi belakang dengan perubahan geometri.

belakang pada Gambar 2 dapat disederhanakan menjadi diagram pada Gambar 3. Kemudian dilakukan modifikasi pada komponen link p-q-r menjadi bentuk geometri pada Gambar $4 \mathrm{~b}$ sedemikian hingga kekakuan pegas yang diinginkan dapat diperoleh. Pada Gambar 4 ditunjukkan perbedaan model sistem suspensi Pro-Link dan sistem suspensi belakang dengan perubahan geometri. Perbedaan antara keduanya terletak pada geometri link-nya.

\section{B. Model Suspensi Geometri}

Suspensi geometri yang dimodelkan mengacu pada diagram Gambar 3 dengan bentuk geometri link $p-q-r$ ditunjukkan pada Gambar 4b. Diagram pada Gambar 3 mengacu model diagram pada penelitian yang dilakukan oleh Simos Evangelou [9]. Simulasi pada numerical software dilakukan pada 3 macam nilai kekakuan pegas, yaitu $25 \mathrm{kN} / \mathrm{m}, 30 \mathrm{kN} / \mathrm{m}$, dan $35 \mathrm{kN} / \mathrm{m}$. Pada masing-masing panjang link atau jarak p-r $5 \mathrm{~cm}, 6,5 \mathrm{~cm}$, dan 8 $\mathrm{cm}$ dilakukan variasi posisi bottom mounting suspensi dengan jarak $q-r 2 \mathrm{~cm}, 4,5 \mathrm{~cm}$, dan $7 \mathrm{~cm}$. Sehingga didapat 27 respon percepatan hasil simulasi.

Simulasi dinamis pada penelitian ini dilakukan dengan memberikan kecepatan kendaraan sebesar $20 \mathrm{~km} / \mathrm{jam}$. Kendaraan yang disimulasikan akan melaju pada profil jalan lurus dengan satu bump (gundukan). Adanya bump pada 
simulasi ini digunakan sebagai eksitasi atau wujud ketidakrataan jalan. Bump tersebut didesain dengan dimensi maksimum yang diizinkan berdasarkan aturan dalam Undangundang Menteri Perhubungan nomor 22 tahun 2009. Hal tersebut dimaksudkan agar respon percepatan yang didapat mudah diamati tetapi masih dalam batas wajar dan dapat ditemui pada kondisi sesungguhnya. Sehingga seteleh respon percepatan tersebut dibandingkan, pengaruh perubahan geometri suspensi dapat diperoleh.

\section{HASIL SIMULASI}

\section{A. Pengaruh Posisi Bottom Mounting Suspensi}

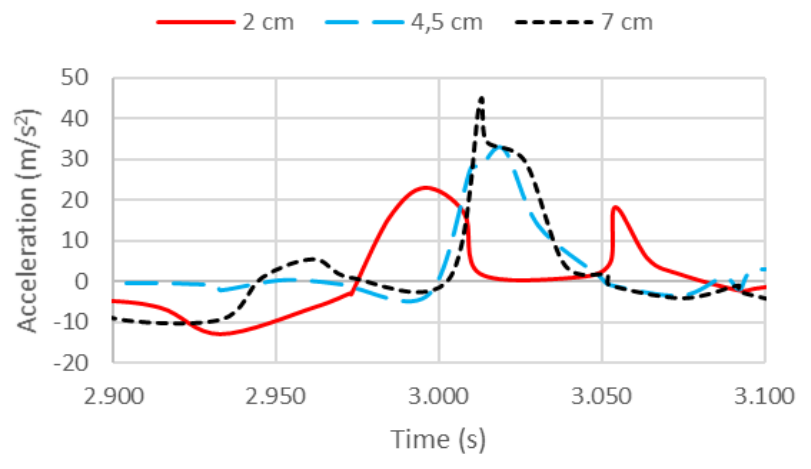

(a)

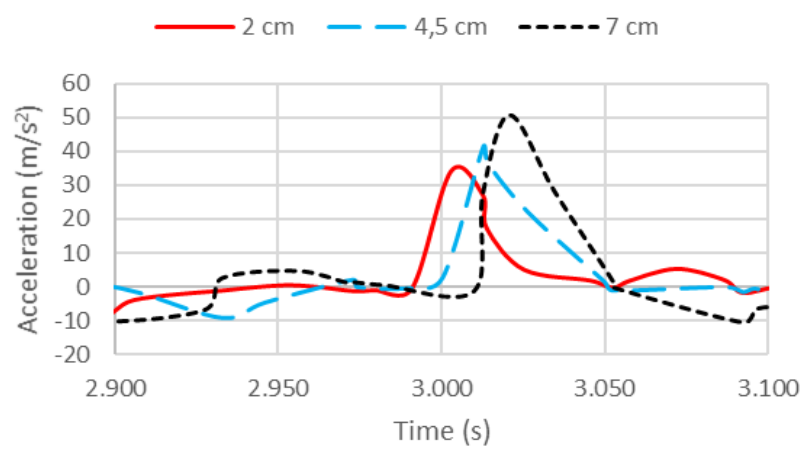

(b)

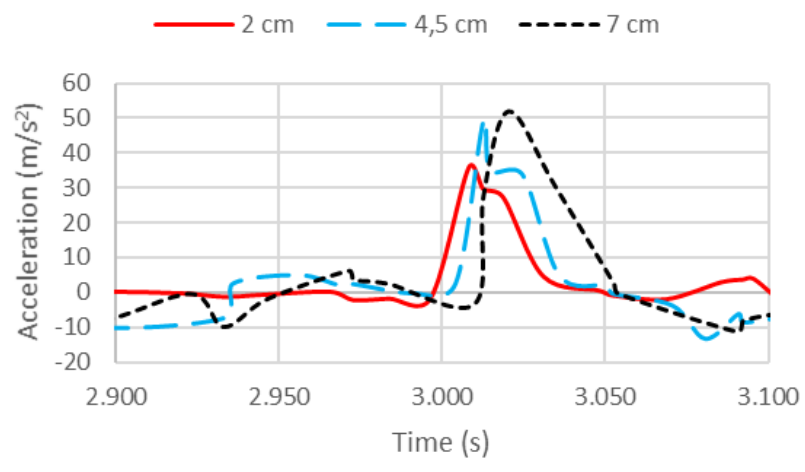

(c)

Gambar 5. Grafik perbandingan respon percepatan hasil simulasi dengan link p-r $5 \mathrm{~cm}$ pada variasi kekakuan pegas (a) $25 \mathrm{kN} / \mathrm{m}$, (b) 30 ar,
Pengambilan data simulasi ini dilakukan dengan mengubahubah posisi bottom mounting suspensi belakang dengan jarak $q-r 2 \mathrm{~cm}, 4,5 \mathrm{~cm}$, dan $7 \mathrm{~cm}$ pada penggunaan nilai kekakuan

Tabel 2.

Defleksi suspensi

\begin{tabular}{|c|c|c|c|c|c|}
\hline \multirow{2}{*}{$\begin{array}{l}\text { Panjang } \\
\text { link } p-r \\
\quad(\mathrm{~cm})\end{array}$} & \multirow{2}{*}{$\begin{array}{c}\text { Kekakuan } \\
\text { pegas } \\
(\mathrm{kN} / \mathrm{m})\end{array}$} & \multirow{2}{*}{$\begin{array}{c}\text { Variasi } \\
\text { Jarak } \\
q-r \\
(\mathrm{~cm})\end{array}$} & \multicolumn{3}{|c|}{ Panjang Supensi } \\
\hline & & & $\begin{array}{l}\text { Maksimum } \\
\quad(\mathrm{mm})\end{array}$ & $\begin{array}{l}\text { Minimum } \\
\text { (mm) }\end{array}$ & $\begin{array}{c}\text { Defleksi } \\
\text { maksimum } \\
(\mathrm{mm})\end{array}$ \\
\hline \multirow{9}{*}{5} & \multirow{3}{*}{25} & 2 & 260 & 223 & 37 \\
\hline & & 4,5 & 258 & 221 & 37 \\
\hline & & 7 & 252 & 217 & 35 \\
\hline & \multirow{3}{*}{30} & 2 & 260 & 223 & 37 \\
\hline & & 4,5 & 257 & 223 & 34 \\
\hline & & 7 & 257 & 224 & 33 \\
\hline & \multirow{3}{*}{35} & 2 & 260 & 226 & 34 \\
\hline & & 4,5 & 260 & 227 & 33 \\
\hline & & 7 & 257 & 227 & 30 \\
\hline
\end{tabular}

pegas dan panjang link $p-r$ yang sama. Respon percepatan untuk berbagai posisi bottom mounting ditunjukkan pada Gambar 5. Pada Gambar 5 dibandingkan nilai percepatan maksimumnya untuk menunjukkan pengaruh perubahan posisi bottom mounting suspensi terhadap respon percepatan yang diperoleh. Dengan nilai kekakuan pegas dan panjang link $p-r$ yang sama, jika semakin kecil nilai jarak $q-r$, maka respon percepatan yang didapat juga semakin kecil. Ini menunjukkan bahwa penggunaan jarak $q-r$ yang lebih panjang menghasilkan kekakuan pegas ekuivalen menjadi lebih besar. Sehingga respon percepatan yang didapat lebih besar.

Dengan menggunakan simulasi yang sama untuk mendapatkan grafik pada Gambar 5, data panjang aktual suspensi pada masing-masing jarak $q-r$ dapat diperoleh. Data tersebut disajikan pada Tabel 2 yang berisi panjang maksimum dan minimum suspensi serta defleksi maksimum yang terjadi. Dengan panjang link dan jarak $q-r$ yang sama, defleksi maksimum yang terjadi pada penggunaan kekakuan pegas yang lebih besar menunjukkan nilai defleksi yang lebih kecil. Sementara itu, pada penggunaan kekakuan pegas dan panjang link yang sama, defleksi maksimumnya menunjukkan nilai yang lebih kecil apabila jarak $q-r$ lebih panjang. Sehingga dapat disimpulkan bahwa posisi bottom mounting suspensi berpengaruh terhadap defleksi maksimum yang terjadi. Berdasarkan hasil simulasi, dibandingkan dengan defleksi maksimum yang dapat diterima oleh suspensi yaitu sebesar 65 $\mathrm{mm}$, defleksi suspensi untuk semua konfigurasi pada penelitian ini bernilai kurang dari batasan ters ebut.

\section{B. Pengaruh Panjang Link}

Pengambilan data simulasi ini dilakukan dengan mengubahubah link $p-r$ dengan panjang $5 \mathrm{~cm}, 6,5 \mathrm{~cm}$, dan $8 \mathrm{~cm}$ pada penggunaan nilai kekakuan pegas dan panjang link $p$-r yang sama. Respon percepatan untuk berbagai panjang $p-r$ ditunjukkan pada Gambar 6. Pada Gambar 6 dibandingkan nilai percepatan maksimumnya untuk menunjukkan pengaruh panjang link terhadap respon percepatan yang diperoleh. Dengan nilai kekakuan pegas dan jarak $q-r$ yang sama, jika 


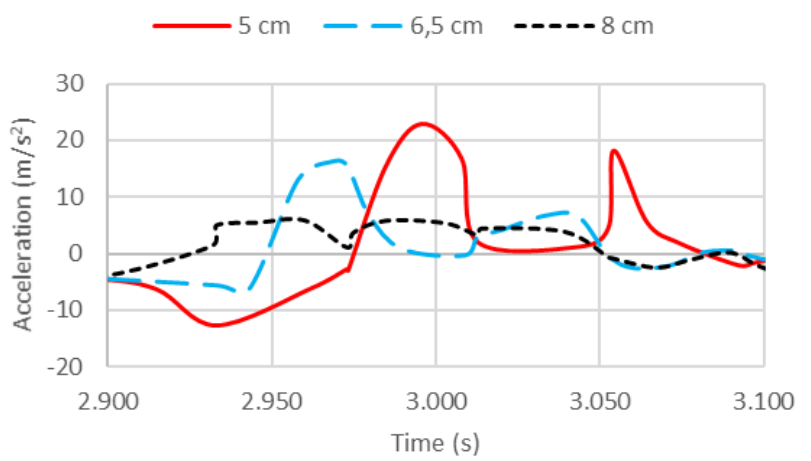

(a)

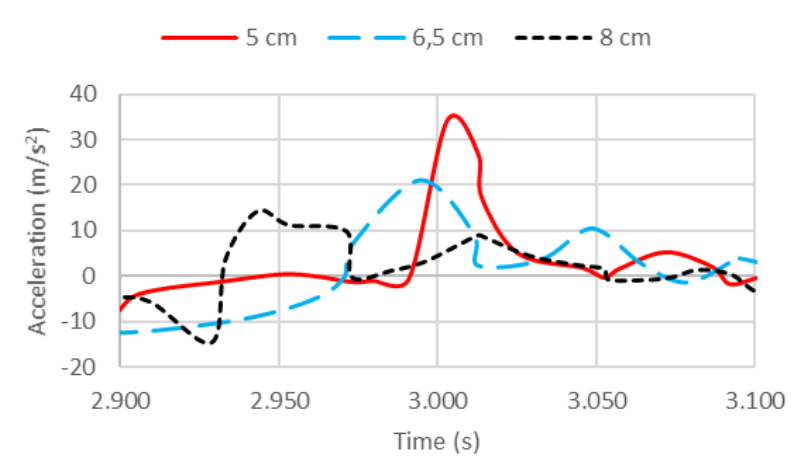

(b)

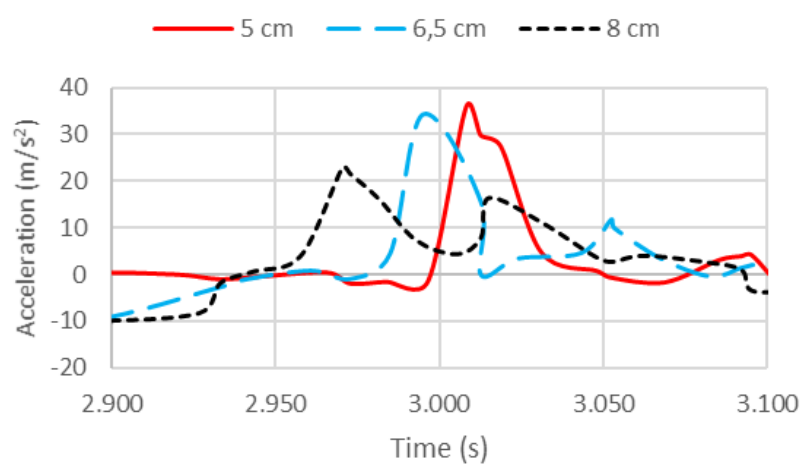

(c)

Gambar 6. Grafik perbandingan respon percepatan hasil simulasi dengan jarak q-r $2 \mathrm{~cm}$ pada variasi kekakuan pegas (a) $25 \mathrm{kN} / \mathrm{m}$, (b) 30 $\mathrm{kN} / \mathrm{m}$. dan

Tabel 3 .

Defleksi suspensi

\begin{tabular}{|c|c|c|c|c|c|}
\hline \multirow{2}{*}{$\begin{array}{c}\text { Jarak } q- \\
r \\
(\mathrm{~cm})\end{array}$} & \multirow{2}{*}{$\begin{array}{c}\text { Kekakuan } \\
\text { pegas } \\
(\mathrm{kN} / \mathrm{m})\end{array}$} & \multirow{2}{*}{$\begin{array}{c}\text { Variasi } \\
\text { Panjang } \\
\text { linkp-r } \\
\text { (cm) }\end{array}$} & \multicolumn{3}{|c|}{ Panjang Supensi } \\
\hline & & & $\begin{array}{l}\text { Maksimum } \\
\quad(\mathrm{mm})\end{array}$ & $\begin{array}{l}\text { Minimum } \\
(\mathrm{mm})\end{array}$ & $\begin{array}{c}\text { Defleksi } \\
\text { maksimum } \\
(\mathrm{mm})\end{array}$ \\
\hline \multirow{8}{*}{2} & \multirow{3}{*}{25} & 5 & 260 & 223 & 37 \\
\hline & & 6,5 & 260 & 218 & 42 \\
\hline & & 8 & 260 & 203 & 57 \\
\hline & \multirow{3}{*}{30} & 5 & 260 & 223 & 37 \\
\hline & & 6,5 & 260 & 221 & 39 \\
\hline & & 8 & 260 & 219 & 41 \\
\hline & \multirow[b]{2}{*}{35} & 5 & 260 & 226 & 34 \\
\hline & & 6,5 & 260 & 224 & 36 \\
\hline
\end{tabular}

semakin kecil panjang liknk $p$-r, maka responopercepattan yang didapat semakin besar. Ini menunjukkan bahwa penggunaan link yang lebih pendek membuat kekakuan pegas ekuivalen menjadi lebih besar. Sehingga respon percepatan yang ditimbulkan pada sasis menjadi lebih besar. Berdasarkan hasil analisis di atas dapat disimpulkan bahwa panjang link mempengaruhi respon getaran pada sasis.

Dengan menggunakan simulasi yang sama untuk mendapatkan grafik pada Gambar 6, data panjang aktual suspensi pada masing-masing panjang $p-r$ dapat diperoleh. Data tersebut disajikan pada Tabel 3, yaitu panjang maksimum

dan minimum suspensi serta defleksi maksimum yang terjadi. Dengan jarak $q-r$ dan panjang link yang sama, defleksi maksimum yang terjadi pada penggunaan kekakuan pegas yang lebih besar menunjukkan nilai defleksi yang lebih kecil. Sementara itu, pada penggunaan kekakuan pegas dengan jarak $q-r$ yang sama, defleksi maksimumnya menunjukkan nilai yang lebih kecil apabila link $p$ - $r$ lebih pendek. Sehingga dapat disimpulkan bahwa panjang link $p$-r berpengaruh terhadap defleksi maksimum yang terjadi.

\section{Perbandingan RMS Percepatan terhadap Suspensi Pro- Link}

Grafik respon RMS percepatan suspensi dengan berbagai variasi geometri dibandingkan dengan suspensi Pro-Link pada Gambar 7. Pengambilan data dilakukan dengan mensimulasikan sistem suspensi pada gambar 4a dengan geometri tetap dan $4 \mathrm{~b}$ dengan variasi panjang link $p-r$ dan posisi bottom mounting suspensi. Rentang waktu yang digunakan untuk memperoleh RMS percepatan pada gambar 4.7 adalah 2,5 hingga 4,1 detik, yaitu sesaat sebelum roda depan menyentuh bump hingga kedua roda melewati bump dan respon percepatan mendekati stabil. Selanjutnya data simulasi diplot untuk memperlihatkan perbandingan RMS percepatannya terhadap suspensi ProLink.

Perbandingan respon RMS percepatan pada gambar 7, ketiganya memperlihatkan bahwa semakin jauh posisi bottom mounting dari titik $r$ atau semakin panjang jarak $q-r$, menghasilkan RMS percepatan yang lebih besar. Gambar 7 juga menunjukkan bahwa nilai RMS percepatan yang lebih rendah secara berurutan dihasilkan oleh panjang link $p-r 8 \mathrm{~cm}$, $6,5 \mathrm{~cm}$, dan yang tertinggi yaitu $5 \mathrm{~cm}$. Pada penggunaan panjang link $p$ - $r$ dan posisi bottom mounting yang sama, jika digunakan kekakuan pegas lebih kecil maka didapat RMS percepatan yang lebih kecil pula.

Sementara itu, pada nilai kekakuan pegas $25 \mathrm{kN} / \mathrm{m}, 30 \mathrm{kN} / \mathrm{m}$ dan $35 \mathrm{kN} / \mathrm{m}$, nilai RMS percepatannya selalu lebih rendah dibandingkan suspensi Pro-Link. Kecuali pada kekakuan pegas $25 \mathrm{kN} / \mathrm{m}$ dengan panjang link $p-r 5 \mathrm{~cm}$ dan jarak $q-r 7$ $\mathrm{cm}$, menghasilkan RMS percepatan yang lebih tinggi daripada RMS percepatan suspensi Pro-Link dengan kekakuan pegas yang sama. Pada gambar 7a ditandai dengan kurva yang saling 

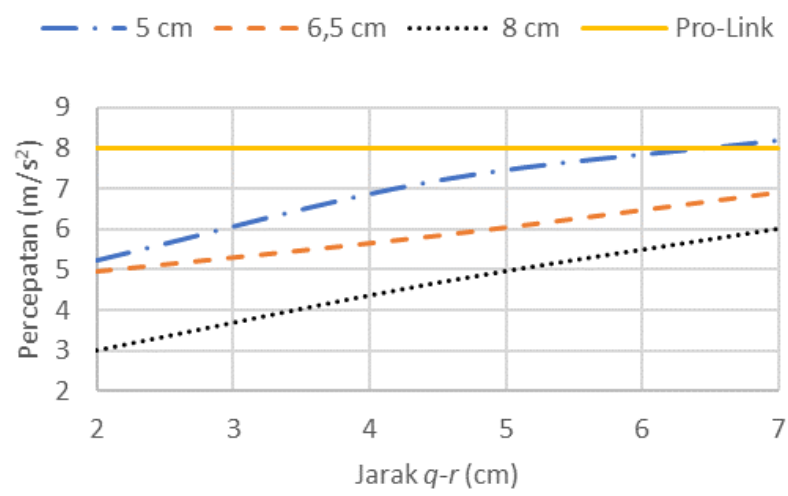

(a)
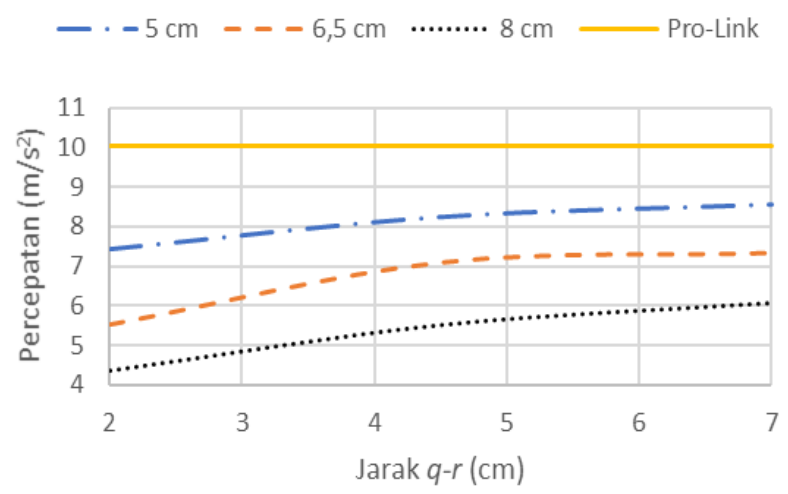

(b)

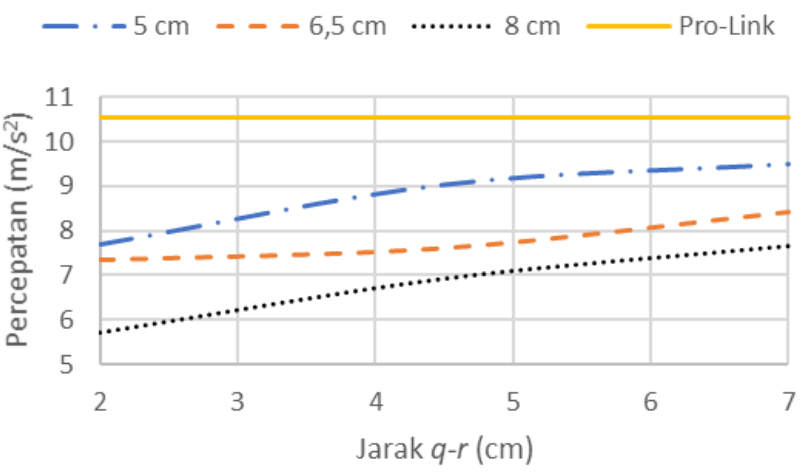

(c)

Gambar 7. Perbandingan respon RMS percepatan terhadap suspensi Pro-Link pada variasi kekakuan pegas (a) $25 \mathrm{kN} / \mathrm{m}$, (b) $30 \mathrm{kN} / \mathrm{m}$, (c) 35 beririsan pada suatu nilai $q-r$ antara $6 \mathrm{~cm}$ dan $7 \mathrm{~cm}$. Ini menunjukkan batas parameter yang menghasilkan performa suspensi yang identik dengan suspensi konvensional ProLink.

Pada penggunaan kekakuan pegas $25 \mathrm{kN} / \mathrm{m}$, RMS percepatan memiliki rentang nilai paling luas dibandingkan dengan kekakuan pegas $30 \mathrm{kN} / \mathrm{m}$ dan $35 \mathrm{kN} / \mathrm{m}$. Selain itu pada kekakuan pegas ini didapatkan nilai RMS percepatan terendah yaitu $3 \mathrm{~m} / \mathrm{s}^{2}$. Berdasarkan analisis di atas dapat disimpulkan bahwa RMS percepatan yang lebih rendah dihasilkan oleh kekakuan pegas yang lebih kecil, link yang lebih panjang, serta jarak $q-r$ yang lebih pendek.

\section{KESIMPULAN}

Pada penelitian ini telah dilakukan analisis pengaruh perubahan geometri suspensi terhadap dinamika getaran sepeda motor. Dari hasil analisis diperoleh bahwa apabila semakin dekat jarak bottom mounting suspensi dengan titik mounting pada connecting rod, maka semakin kecil pula respon percepatan yang diperoleh. Jika link semakin panjang, maka semakin kecil respon percepatan yang diperoleh. Dan apabila semakin kecil nilai kekakuan pegas yang digunakan, semakin kecil pula respon percepatan yang diperoleh. Sehingga dapat disimpulkan pula bahwa perubahan posisi bottom mounting suspensi dan panjang link mempengaruhi nilai kekakuan pegas ekuivalen. Selain itu, berdasarkan hasil simulasi, dibandingkan dengan suspensi Pro-Link, sistem suspensi yang dipelajari pada penelitian ini memberikan respon percepatan yang lebih baik.

\section{DAFTAR PUSTAKA}

[1] D. Xue et al., "Study of Art of Automotive Active Suspensions," in International Conference on Power Electronics Systems and Applications, 2011, pp. 1-7.

[2] S. A. Arana, Evangelou, and D. Dini, "Series Active Variable Geometry Suspension for Road Vehicles," in IEEE/ASME Transactions On Mechatronics, 2013, pp. 1-3.

[3] P. J. P. J. T. Venhovens, A. C. M. K. van Der, and H. B. Pacejka, "Semi-active attitude and vibration control," Vehicle System Dynamics," Veh. Syst. Dyn., vol. 22, no. 5-6, pp. 359$381,1993$.

[4] N. J. Leighton and J. Pullen, "A novel active suspension system for automotive application," in Proceedings of the Institution of Mechanical Engineers Part D-Journal of Automobile Engineering, 1994, pp. 243-250.

[5] D. Karnopp and S. G. So, "Energy flow in active attitude control suspensions: A bond graph analysis," Veh. Syst. Dyn., vol. 29 , no. 2 , pp. $69-81,1998$.

[6] Watanabe and R. S. Sharp, "Mechanical and control design of a variable geometry active suspension system," Veh. Syst. Dyn., vol. 32, no. 2-3, pp. 217-235, 1999.

[7] W. J. Evers, A. K. van Der, I. Besselink, and H. Nijmeijer, "Modeling, analysis and control of a variable geometry actuator," in IEEE Intelligent Vehicles Symposium (IV). Eindhoven, 2008, pp. 251-256.

[8] S. A. Evangelou, C. Kneip., M. Dini, and Tocatlian, "Variable Geometry Suspension Apparatus and Vehicle Comprising such Apparatus," 2010.

[9] S. A. Evangelou, "Control of Motorcycles by Variable Geometry Rear Suspension," in IEEE Internasional Conference on Control Applications, 2010. 